\title{
Maladaptive behavior in relation to the basic psychological needs of students in secondary education
}

\author{
R. J. Oostdam ${ }^{1,2}$ (D) • M. J. C. Koerhuis ${ }^{1}$ - R. G. Fukkink ${ }^{1,2}$
}

Received: 2 November 2017 / Revised: 24 May 2018 / Accepted: 29 June 2018 /

Published online: 10 July 2018

(C) The Author(s) 2018

\begin{abstract}
Much research has been done into the relationship between students' motivation to learn and their basic psychological needs as defined by the self-determination theory (autonomy, competence, relatedness). However, few studies have explored how these psychological needs relate to different types of maladaptive behavior in the classroom. To prevent or remedy such behavior, more insight into its relationships is required. The present study attempted to determine the relationship between maladaptive behavior of secondary school students (grades 8 and 9) and the degree to which both teachers and peers address their needs for competence, autonomy, and relatedness. Results show significant, negative correlations between maladaptive student behavior in the classroom and the extent to which students' basic psychological needs are met by teachers and fellow students. Both teachers and fellow students play a role in students' maladaptive behavior toward school and withdrawn behavior. When it comes to unfriendly behavior, the perceived support of teachers appears to be particularly relevant, while the role of peers is an important factor in delinquent behavior.
\end{abstract}

Keywords Maladaptive behavior Antisocial behavior - Motivation - Self-determination theory Secondary education

R. J. Oostdam

r.j.oostdam@hva.nl

M. J. C. Koerhuis

m.c.koerhuis@hva.nl

R. G. Fukkink

r.g.fukkink@hva.nl

1 Centre for Applied Research in Education (CARE), Amsterdam University of Applied Sciences, Wibautstraat 2-4, 1091 GM Amsterdam, The Netherlands

2 Research Institute of Child Development and Education (RICDE), University of Amsterdam, Amsterdam, The Netherlands 


\section{Introduction}

In the widest sense, students' maladaptive behavior at school can be defined as "any type of behavior by students in a classroom or school environment that violates a written or unwritten social norm or school rule" (Koerhuis and Oostdam 2014). Maladaptivity can pertain to a wide variety of behavior, ranging from outright delinquency to far more subtle forms of disruptive or antisocial behavior. In addition, maladaptive behavior can be aimed at specific people (e.g., supervisors, teachers, or peers), or more generalized, targeting anyone and anything. Finally, the behavior can be an isolated event or recurring. This broad definition of maladaptive behavior is in accordance with several descriptions used in various research reports (cf. Olweus et al. 1986; Van der Ploeg 2007; Van der Wolf and van Beukering 2009).

It is well known that maladaptive behavior increases with age and peaks during adolescence (Moffitt 1993). Biological changes (hormonal changes and neurological development) could account for this, as could the influence of social environmental factors such as the growing importance of peers (Murteira Morgado and Da Luz Vale-Dias 2013) and the widening gap between students' personal lives and interests and the school environment (Eccles and Roeser 2009). Much research has been done to the role of the family environment concerning socioeconomic status, parents' traits, and upbringing (cf. Dornbusch et al. 2001; Vazsonyi and Pickering 2000); the effects of developmental disorders (because of ADHD, for instance) and individual characteristics such as gender and degree of impulsiveness (cf. LeBlanc et al. 2008; Murteira Morgado and Da Luz ValeDias 2013); and school-related factors such as the influence of teacher involvement and the impact of inadequate classroom management (cf. Roorda et al. 2011). Results of this research also consistently showed that male students are prone to display more externalized maladaptive behavior at school than female students (cf. Koerhuis 2007; Koerhuis and Oostdam 2014). This finding pertains to both delinquent behavior (Van der Laan and Blom 2006) and truancy (Veenstra et al. 2010). Female students, however, tend to display more internalized behavioral problems in the classroom than their male counterparts (Dutch Education Council 2010).

Many of these studies explored specific types of maladaptive or delinquent behavior of youths in non-school environments, like bullying or substance abuse (see Maguin and Loeber 1995; Moffit \& Caspi 2001; Séguin et al. 2009). However, the present study pertains to common types of disruptive behavior in the classroom, such as classroom inattentiveness, talking, refusing to get to work, or using a variety of excuses not to have to do assignments. It also includes less common types of behavior, such as ridiculing or name-calling aimed at teachers and fellow students. Such school behavior potentially affects not only the students who act this way but also their immediate surroundings. It can cause teacher stress, impair the teaching environment, and prevent fellow students from learning (Dutch Education Council 2010). At the same time, students who display maladaptive behavior may prevent themselves from learning. This may cause them to fall behind in their studies, being demoted to a lower level of education or dropping out of school altogether (cf. Meijers et al. 2006; Peetsma and Van der Veen 2011). In the worstcase scenario, these students' maladaptive behavior becomes more pronounced, which, in the long run can result in their displaying delinquent behavior, encountering the police and the justice system, developing psychiatric disorders, and generally dropping out of society (Fergusson et al. 2005; Moffitt et al. 2002). This phenomenon is an important argument for taking preventive and curative measures at schools. 


\section{Psychological needs of students}

There is no single cause for maladaptive behavior at school. Underlying causes often include motivational and/or personal problems (Meijers et al. 2006; Peetsma and Van der Veen 2011). This study is specifically related to underlying motivational aspects (Pintrich and Schunk 2002). Based on Deci and Ryan's (2000) theory of self-determination, we argue that students' motivation partly depends on the extent to which their own psychological needs, that is to say their need to feel autonomous, competent, and related to others, are met. Various studies have shown that teachers' ability to meet these three basic psychological needs correlates with outcomes at student level, such as increased motivation, better self-regulation, better scholastic achievement, and increased well-being (cf. Schuit et al. 2011; Vansteenkiste et al. 2012). However, the relation between the extent to which teachers meet the basic needs and maladaptive student behavior at school has been studied by only a handful of researchers (Vansteenkiste et al. 2012; Koerhuis and Oostdam 2014).

Vansteenkiste et al. (Vansteenkiste et al. 2008, 2012) examined the relation between students' motivation, learning outcomes, and maladaptive behavior in relation to the extent that teachers meet their need for autonomy and provide sufficient structure. Participants were 1036 students in grades 7 through 12 of the vocational and academic track in secondary education in Belgium. In general, results show that students who perceived their learning environment as a teaching configuration with low autonomy support and less structure showed, on average, less motivation, lower scores, and more problem behavior in comparison to students who perceived high autonomy support and respectively sufficient of insufficient structure. Students characterized by a varying combination of a high level of perceived autonomy support and sufficient or insufficient perceived structure did not differ in terms of problem behavior, suggesting that in particular, autonomy support is related to less problem behavior. From an applied perspective, the recommendation was made that teachers might best create an autonomy supportive instead of a controlling learning environment in which there is hardly any room for learner autonomy (Vansteenkiste et al. 2012, p. 438). In the study of Koerhuis and Oostdam (2014), the relationship between problem behavior in the classroom and the extent to which students experience that teachers meet their three needs was examined. Participants were 190 students in grades 8 and 9 of the lower vocational track of Dutch secondary education. Results showed a significant relation between maladaptive behavior of students and the extent to which teachers met their three psychological needs. In addition, a grade effect was found. The correlation between problem behavior and the extent to which students perceive that teachers met their needs increased significantly in grade 9, indicating that the support of the psychological needs by teachers is becoming increasingly important as students grow older.

As these studies show, Deci and Ryan's self-determination theory (SDT) offers a theoretical framework to analyze the relation between the basic psychological needs of students and their maladaptive behavior at school. The theory distinguishes between amotivation, intrinsic motivation, and extrinsic motivation. Amotivated students lack motivation to carry out a cognitive task because they do not see its relevance or they feel incompetent. Intrinsically motivated students, however, carry out cognitive tasks because they find them interesting and captivating. Extrinsically motivated students carry out cognitive tasks not out of interest but rather to achieve a secondary goal. The SDT distinguishes between several types of extrinsically regulated motivation (Deci and Ryan 2000): external regulation, which results from an expected reward or punishment; introjected regulation, based on an expected internal reward 
such as appreciation or forestalling feelings of guilt; regulation through identification, resulting from recognition of the value of a cognitive task (e.g., a student who is not very interested in math is aware of the fact that they need a passing grade in order to get into university); and integrated regulation, or execution of a cognitive task because it matches the student's own values and norms (e.g., learning a foreign language because the student finds that important for his or her own personal development).

Students who carry out cognitive tasks based on intrinsic motivation or on extrinsic motivation regulated through identification or integration do so because they themselves want to. There is no pressure or coercion. For this reason, these are also referred to as autonomous types of motivation (Deci and Ryan 2000). When students are autonomously motivated, their learning is more conscious, self-regulated, and self-managed, according to SDT. Ultimately, this results in more "deep learning," an ability to meaningfully apply knowledge and skills in varying contexts (Vansteenkiste et al. 2008). Students are particularly motivated when their teachers provide a learning environment with challenging and meaningful tasks. Another important factor is how well teachers in such a learning environment are attuned to their students. Hence, SDT explicitly links autonomous motivation with the extent to which the learning environment adequately provides for students' basic psychological needs and allows them to feel competent, autonomous, and related to other people (Reeve et al. 2004).

\section{Competence, autonomy, and relatedness}

Within SDT, competence is defined as the need for students to act successfully and effectively and the volition to learn something (Deci and Ryan 2000). When students repeatedly experience that their efforts do not yield the desired result, they will start to feel incompetent and put in less and less effort. Such negative experiences will decrease students' motivation to learn, which, in turn, may encourage maladaptive behavior. Hence, it is important to reinforce students' conviction that they can master the curriculum and successfully finish cognitive tasks. One essential precondition is a challenging learning environment with clear goals and clear expectations accompanied by differentiated instruction, support, and feedback (cf. Oostdam et al. 2007; Jang et al. 2010; Niemiec and Ryan 2009; Schuit et al. 2011). Giving positive feedback about what goes well makes students feel competent and fosters motivation, while negative feedback about things that still go wrong tends to instill a sense of incompetence and demotivation (Hattie and Timperley 2007).

The SDT defines autonomy as students' need to set, pursue, and attain their own goals, values, and interests (cf. Deci and Ryan 2000). In a motivating learning environment with latitude for autonomy, students are given the opportunity to work on personal learning objectives, are allowed to make choices in their personal learning process, and have, in their perception, a choice in carrying out tasks they consider relevant. Teachers who want to foster a sense of autonomy give their students sufficient options to act based on their personal interests and learning needs. They might let students have a voice in decisions about certain tasks, for example, by encouraging them to introduce their own topics, ideas, or opinions (Niemiec and Ryan 2009). Studies have shown a positive correlation between the degree of autonomy students feel they have and their level of motivation to learn (cf. Deci et al. 1999; Standage et al. 2006). In a learning environment in which students experience little or no autonomy, learning motivation can decrease with maladaptive classroom behavior as a result.

Relatedness refers to the extent to which students feel connected, safe, and respected. When students feel truly appreciated and respected by their teachers, they are more willing to respect 
the values, norms, rules, and regulations at school (Niemiec and Ryan 2009). Several studies have shown that a good understanding between teacher and student encourages motivation and scholastic achievement and helps to prevent maladaptive behavior (cf. Roorda et al. 2011; Schuitema et al. 2016; Vansteenkiste et al. 2012).

\section{Supporting role of teachers}

This study in the first place investigates the general hypothesis that the extent to which teachers meet their students' need to feel competent, autonomous, and relatedness is an important factor that decreases the likelihood that students will display maladaptive behavior in the classroom. In adolescence, students are developing rapidly and have a growing need to get confirmation that they are able to achieve something. Moreover, they increasingly want to make their own decisions. At the same time, they put great stock in their relationships with others who they are looking to for acceptance, respect, and understanding. Teachers who do not sufficiently meet these basic needs of their students could therefore be more confronted with maladaptive behavior as teachers who take these needs more into account. This resulted in the following hypothesis: teachers who meet the three basic psychological needs of their students are confronted with less maladaptive behavior as teachers who did not meet their students' basic needs. To investigate this hypothesis, the present study examines the relationship between students' maladaptive behavior at school and the degree to which they feel that their need for competence, autonomy, and relatedness is met by their teachers.

\section{Supporting role of peers}

While teachers play a key role regarding students' three basic psychological needs of competence, autonomy, and relatedness, they are not the only relevant actors in the school context. At school, students spend most of their time in the presence of, and interacting with, other students. Their peers can also have great impact on whether students feel their sense of competence, autonomy, and relatedness is promoted or thwarted. For example, fellow students can consciously or subconsciously have a negative impact on a classmate's sense of competence or relatedness by refusing to work together, repeatedly making negative comments, or bullying. On the other hand, students can also foster their peers' sense of competence and autonomy by supporting them and leaving them room to pursue their own goals. Peers can be very influential, particularly when working on school projects together. Research has shown that cooperating on a cognitive task can positively affect students' learning performance, motivation, and sense of competence (cf. Pintrich and Schunk 2002; Schuit et al. 2011; Oostdam et al. 2007). Other studies have shown that a close bond between students has positive effects, including fewer dropouts and less truancy, better scholastic achievement, and greater motivation for school activities (Helwig 2006; O'Moore and Kirkham 2001). Conversely, a troubled relationship with classmates has been shown to correlate with a poorer sense of well-being and lower motivation and academic achievement (cf. Sheldon and Bettencourt 2002; Wentzel 1996).

As regards peers, we assume their role in supporting students' needs might have a relation with maladaptive behavior as well (cf. Berndt and Keefe 1996). It is assumed that a low level of need support by fellow students is negatively correlated with problem behavior. Therefore, a second hypothesis is postulated: the extent to which students meet each other's basic psychological needs decreases the likelihood that students will display maladaptive behavior in the 
classroom. To explore this second hypothesis, we examine to what extent students feel that their need for competence, autonomy, and relatedness is met by their fellow students and, subsequently, we investigate the empirical relationship between students' maladaptive behavior at school and the degree to which they feel their fellow students meet their basic psychological needs.

\section{Method}

The study was conducted in the 2013-2014 academic year at several Dutch secondary schools. Compulsory primary education in the Netherlands lasts for 8 years (2 years of nursery class, followed by six grades), after which all children are referred to the different tracks in secondary education: prevocational secondary education (4 years), general secondary education (5 years), and pre-university secondary education (6 years). Students in grades 8 and 9 from the prevocational (VOC), general (GEN), and pre-university (UNI) level were asked to fill out questionnaires about their socially maladaptive behavior and the extent to which, in their perception, their need for competence, autonomy, and relatedness was met by their teachers and peers.

\section{Sample}

Table 1 shows the distribution of the sample among the three educational levels. A total of 585 students took part, from 27 groups in nine different schools in the Dutch provinces of North Holland, South Holland, and Utrecht (see Table 1).

We collected demographic data on the students, including their cultural background and their parents' level of education. Although some of the students feel connected with other cultures (Turkish, Moroccan, Surinamese, Antillean, etc.), the majority indicated that they identify themselves as Dutch.

Table 1 Descriptive statistics for secondary educational levels (VOC = pre-vocational secondary education; GEN = general secondary education; UNI = pre-university secondary education), grade, and gender (absolute numbers, followed by percentages in parentheses)

\begin{tabular}{|c|c|c|c|c|c|c|c|}
\hline \multirow[b]{2}{*}{ Grade } & \multicolumn{2}{|c|}{$\operatorname{VOC}(N=137)$} & \multicolumn{2}{|c|}{$\operatorname{GEN}(N=219)$} & \multicolumn{2}{|c|}{ UNI $(N=229)$} & \multirow[t]{2}{*}{ Total } \\
\hline & 8 & 9 & 8 & 9 & 8 & 9 & \\
\hline$N$ per grade & 31 & 106 & 124 & 95 & 80 & 149 & 585 \\
\hline \multicolumn{8}{|l|}{ Gender } \\
\hline Male & $18(58)$ & $42(40)$ & $67(54)$ & $38(40)$ & $46(58)$ & $62(42)$ & $273(47)$ \\
\hline Female & $13(42)$ & $61(57)$ & $57(46)$ & $54(55)$ & $34(43)$ & $86(58)$ & $305(52)$ \\
\hline Unknown & - & $3(3)$ & - & $3(5)$ & - & $1(0)$ & $7(1)$ \\
\hline \multicolumn{8}{|l|}{ Father's education level } \\
\hline Low & $7(23)$ & $14(13)$ & $21(17)$ & 15 (16) & 15 (19) & $26(17)$ & 98 (17) \\
\hline Medium & $9(29)$ & $34(32)$ & $39(31)$ & $19(20)$ & $19(24)$ & $32(22)$ & $152(26)$ \\
\hline High & $10(32)$ & $38(36)$ & $46(37)$ & $49(52)$ & $41(51)$ & $75(50)$ & $260(44)$ \\
\hline \multicolumn{8}{|c|}{ Mother's education level } \\
\hline Low & $5(16)$ & $18(17)$ & $23(18)$ & $14(15)$ & $18(22)$ & $10(7)$ & $88(15)$ \\
\hline Medium & $11(36)$ & $39(37)$ & $51(41)$ & $16(17)$ & $20(25)$ & $35(24)$ & $172(29)$ \\
\hline High & $11(36)$ & $36(34)$ & $34(27)$ & $52(55)$ & $36(45)$ & $86(58)$ & $254(43)$ \\
\hline Identification as Dutch & $21(68)$ & $77(73)$ & $103(83)$ & $75(79)$ & $71(89)$ & $130(87)$ & $477(82)$ \\
\hline
\end{tabular}




\section{Procedure}

Questionnaires (see "Measures") were administered by six test leaders between March and June 2014, always in the presence of a teacher. In accordance with the ethical rules of the university, the school had previously informed students' parents/caretakers in a personal writing about the study and given them an opportunity to object to their child taking part. None of the parents/caretakers objected. The questionnaires were compiled in a booklet that was handed out at the beginning of a lesson. The test leaders introduced the questionnaires and were available for practical questions while the students filled them out. Students had a maximum of $50 \mathrm{~min}$, and it took them $20 \mathrm{~min}$, on average, to fill out all four questionnaires. None of the students needed the full $50 \mathrm{~min}$. Afterwards, the test leaders personally collected the booklets from the students.

\section{Measures}

The first measure was the "Questionnaire on Socially Maladaptive Behavior at School" (Koerhuis 2007; Koerhuis and Hijzen 2009). This questionnaire on socially maladaptive behavior at school (SMBS) comprised 43 items on four types of maladaptive behavior at school: (1) maladaptive behavior toward school and schoolwork (15 items, e.g., "distracting others"), (2) unfriendly behavior (8 items, e.g., "provoking other students"), (3) withdrawn behavior (9 items, e.g., "not participating in classroom discussions"), and (4) delinquent behavior (11 items, e.g., "destroying school property"). Students were asked to indicate on a 5 -point scale ( 1 = never, 2 = not often, $3=$ sometimes, $4=$ often, $5=$ very often $)$ how often they had displayed a particular type of behavior at school over the last 3 months. This questionnaire has been validated for the different educational levels in the Netherlands (Koerhuis 2007; Koerhuis and Hijzen 2009). These studies compared students' self-reported scores with teachers' scores on a version of the questionnaire for teachers. The students' scores were also compared to their scores on the "Youth Self Report" (Achenbach and Edelbrock 1986), while the teachers' scores were compared to their scores on the "Teacher's Report Form" (Achenbach 1991). Based on these validation studies, the COTAN (Dutch Committee on Tests and Testing, part of the Dutch Association of Psychologists) evaluated the questionnaire as sufficient. Reliability (Cronbach's $\alpha$ ) of the various scales in the present study ranged from .81 to .89 .

A second questionnaire, the "Teacher As Social Context Questionnaire" (TASCQ-Short Form; Belmont et al. 1992) asked students to indicate the extent to which they felt that their teachers provided for their need for competence (eight items, e.g., "My teachers show me how to solve problems for myself"), autonomy (eight items, e.g., "My teachers listen to my ideas"), and relatedness (eight items, e.g., "My teachers really care about me"). Students were asked to respond to these statements on a 5 -point scale $(1=$ not at all true, $2=$ not true, $3=$ neither true nor false, $4=$ true, $5=$ very true). The Dutch version was translated in accordance with international guidelines, validated by Sierens et al. (2009), and used in various studies (cf. Koerhuis and Oostdam 2014; Sierens et al. 2009; Vansteenkiste et al. 2012). Reliability (Cronbach's alpha) of the three scales in this study was found to be sufficient (ranging from .70 to .77$)$.

To assess the extent to which students felt their peers met the three basic psychological needs, we adapted the TASCQ-Short Form to a peer-oriented questionnaire. To this end, we reformulated each item, usually by substituting the word "teachers" for the word "peers." For 
example, the statement "My teachers listen to my ideas" was replaced by "My peers listen to my ideas." When such substitution resulted in an irrelevant item, the item was stricken. To strengthen the scale, we also added several items; for example in the competence scale, we added the statement "My peers help me understand the material." The original questionnaire comprised 21 items (six items on competence; seven on autonomy; eight on relatedness). Using a principal component analysis with varimax rotation, we ultimately arrived at an optimum structure with four items for the autonomy subscale and five items each for the competence and relatedness subscales. The explained variance of the relatedness and competence factors was $22 \%$ for both, with cross-loadings ranging from - .01 to .19 and from -.15 to .25 , respectively. The explained variance of autonomy was $15 \%$, with cross-loading ranging from -.07 to .24 . Reliability of the three subscales for peer-supported competence, autonomy, and relatedness was adequate ( $\alpha$ between .70 and .84$){ }^{1}$

To control for socially desirable responses, we included a shortened version of the Marlowe-Crowne social desirability questionnaire, comprised of 11 dichotomous items (agree/do not agree). This questionnaire, which was validated for the Dutch context by Nederhof (1981), was sufficiently reliable in this study $(\alpha=.77)$.

\section{Analyses}

Taking the hierarchical structure of the data into account with students nested in classes and classes nested in schools, we used multilevel regression analysis with a student, class, and school level (levels 1, 2, and 3, respectively) for the different outcome measures of the SMBS questionnaire. The equation for the level 1 model is as follows: $Y_{i j k}=\beta_{0 i j k}+\beta_{1} x_{i j k}$, where $Y_{i j k}$ is the SMBS score for an individual student $i$ (level 1) in class $j$ (level 2) and in school $k$ (level 3) and $x_{i j k}$ are predictors from our model with corresponding beta weights $\left(\beta_{1}\right)$. For level 2 , the equation is as follows: $\beta_{0 j k}=\beta_{0}+v_{0 k}+u_{0 j k}+e_{0 i j k}$, where $\beta_{0 j k}$ is the random intercept, $v_{0 k}$ is the random effect at the school level, $u_{0 j k}$ is the random effect at the class level, and $e_{i j k}$ is the random effect at the student level. All analyses were conducted with MLwiN, version 2.10, using iterative generalized least squares estimation (Rasbash et al. 2009). Continuous variables (the SDT predictors at teacher and student level) were centered at the grand mean.

In line with the logic of hierarchical regression analysis, background variables were entered into each model first to statistically control for their relations and to determine subsequently whether the theoretical variables from the SDT could explain additional variance of the outcome measures. Each model takes into account students' background variables (gender, grade, educational level, parents' level of education), as well as social desirability bias and the extent to which students identified themselves as Dutch. Next, the needs for competence, autonomy, and relatedness at both teacher and peer levels were added as theoretical predictors. We included background variables to be able to determine relatively robust correlations between the theoretical variables and students' maladaptive behavior. We also analyzed whether interactions between statistically significant background variables and other background variables were statistically significant.

Finally, the scores for the outcome measures were transformed to better approach a normal distribution. We applied a root transformation for maladaptive and withdrawn behavior, which proved helpful in approximating a normally distributed variable. For the outcome measure unfriendly behavior, a root transformation was less successful, but a log transformation proved

${ }^{1}$ The full TASCQ for peers is available from the authors on request. 
more adequate in approximating a normal distribution for this outcome measure. The score for delinquent behavior, which was rare and showed floor effects, was dichotomized: $0=$ the student did not report delinquent behavior on any of the items (corresponding to score 1 "never" in the SMBS questionnaire), while $1=$ the student reported delinquent behavior at least once (scores greater than 1, ranging from "not very often" to "very often"). This dichotomous score means that a single incidence or a subtle form of delinquency is subsumed in this term.

In an additional analysis, we compared the statistical results between our final models including background variables (see Table 3) and excluding these variables. The results remained generally similar in both multilevel regression models, indicating the robustness of the outcomes of our analysis.

\section{Results}

Table 2 shows the average summed scores for each of the questionnaires' subscales, broken down according to gender, grade, and educational level. Regarding the SMBS results of the total sample, the average summed scores on the 5-point scale show that students reported relatively little maladaptive behavior. Especially delinquent behavior was rarely reported. The overall averages for maladaptive behavior toward school and schoolwork, unfriendly behavior,

Table 2 Mean score (and SD), broken down by gender, grade, and educational level (VOC = pre-vocational secondary education; GEN = general secondary education; UNI = pre-university secondary education)

\begin{tabular}{|c|c|c|c|c|c|c|c|c|}
\hline Scales & $\begin{array}{l}\text { Overall } \\
(N=585)\end{array}$ & $\begin{array}{l}\text { Males } \\
(N=272)\end{array}$ & $\begin{array}{l}\text { Females } \\
(N=303)\end{array}$ & $\begin{array}{l}\text { Grade } 8 \\
(N=234)\end{array}$ & $\begin{array}{l}\text { Grade } 9 \\
(N=349)\end{array}$ & $\begin{array}{l}\text { VOC } \\
(N=137)\end{array}$ & $\begin{array}{l}\text { GEN } \\
(N=219)\end{array}$ & $\begin{array}{l}\text { UNI } \\
(N=229)\end{array}$ \\
\hline $\begin{array}{l}\text { School and } \\
\text { school- } \\
\text { work }\end{array}$ & $2.10(.67)$ & $2.22(.74)$ & $2.00(.59)$ & $1.96(.62)$ & $2.20(.69)$ & $2.28(.77)$ & $2.08(.64)$ & $2.02(.62)$ \\
\hline $\begin{array}{l}\text { Unfriendly } \\
\text { behavior }\end{array}$ & $1.55(.66)$ & $1.75(.77)$ & $1.38(.38)$ & $1.43(.59)$ & $1.63(.70)$ & $1.72(.82)$ & $1.53(.59)$ & $1.47(.61)$ \\
\hline $\begin{array}{l}\text { Withdrawn } \\
\text { behavior }\end{array}$ & $1.97(.62)$ & $.97(.63)$ & $1.96(.60)$ & $1.80(.53)$ & $2.08(.64)$ & $2.18(.70)$ & $1.96(.60)$ & $1.85(.55)$ \\
\hline $\begin{array}{r}\text { Delinquent } \\
\text { behavior }\end{array}$ & $1.16(.49)$ & $1.25(.65)$ & $1.06(.26)$ & $1.10(.37)$ & $1.19(.55)$ & $1.30(.75)$ & $1.14(.38)$ & $1.09(.35)$ \\
\hline $\begin{array}{l}\text { Teacher } \\
\text { compe- } \\
\text { tence }\end{array}$ & $3.18(.56)$ & $3.12(.59)$ & $3.24(.52)$ & $3.26(.57)$ & $3.13(.55)$ & $2.89(.57)$ & $3.20(.56)$ & $3.34(.48)$ \\
\hline $\begin{array}{l}\text { Teacher } \\
\text { autonomy }\end{array}$ & $3.24(.53)$ & $3.15(.59)$ & $3.33(.46)$ & $3.34(.54)$ & $3.18(.52)$ & $2.98(.57)$ & $3.28(.51)$ & $3.36(.48)$ \\
\hline $\begin{array}{l}\text { Teacher } \\
\quad \text { relatedness }\end{array}$ & $3.30(.58)$ & $3.24(.61)$ & $3.35(.54)$ & $3.29(.58)$ & $3.30(.58)$ & $3.10(.57)$ & $3.30(.59)$ & $3.41(.54)$ \\
\hline $\begin{array}{l}\text { Peer } \\
\quad \text { compe- } \\
\text { tence }\end{array}$ & $3.07(.78)$ & $2.91(.76)$ & $3.21(.54)$ & $3.04(.80)$ & $3.10(.77)$ & $2.80(.78)$ & $3.00(.81)$ & $3.30(.59)$ \\
\hline $\begin{array}{l}\text { Peer } \\
\text { autonomy }\end{array}$ & $4.02(.60)$ & $3.98(.66)$ & $4.06(.54)$ & $4.09(.55)$ & $3.97(.62)$ & $3.90(.69)$ & $4.06(.59)$ & $4.07(.53)$ \\
\hline $\begin{array}{l}\text { Peer, } \\
\quad \text { relatedness }\end{array}$ & $3.68(.76)$ & $3.65(.72)$ & $3.69(.62)$ & $3.73(.67)$ & $3.64(.67)$ & $3.47(.78)$ & $3.66(.66)$ & $3.82(.60)$ \\
\hline $\begin{array}{l}\text { Social } \\
\quad \text { desirability }\end{array}$ & $1.45(.27)$ & $1.50(.30)$ & $1.40(.24)$ & $1.45(.28)$ & $1.44(.27)$ & $1.43(.23)$ & $1.48(.26)$ & $1.41(.25)$ \\
\hline
\end{tabular}


and withdrawn behavior are higher but still tend toward the lower end of the Likert scale. All SMBS subscales show large standard deviations, however. This indicates large differences between individual students in terms of how much maladaptive behavior they report. In the classroom, this translates into many students rarely or never displaying maladaptive behavior and some students frequently engaging in this type of behavior.

\section{Satisfaction of psychological needs: teachers and peers}

The responses to the TASCQ for teachers resulted, on average, in a neutral score on the 5-point Likert scale ( $1=$ not at all true, $2=$ not true, $3=$ neither true nor false, $4=$ true, $5=$ very true $)$ for each of the competence, autonomy, and relatedness subscales (scores were 3.18, 2.34, and 3.30 , respectively). By contrast, the responses to the TASCQ for peers yielded relatively high scores for the autonomy and relatedness scales (mean scores are 4.02 and 3.68, respectively). The score on the competence scale is lower than that for autonomy and relatedness, for both teachers and peers (mean scores are 3.18 and 3.07, respectively; see also Table 3). In other words, students felt that their need for autonomy and relatedness was better satisfied by their peers than by their teachers (autonomy: $t_{\text {paired }}(584)=25.7, p<.001$, and relatedness: $t_{\text {paired }}$ $(584)=12.2, p<.001)$. However, teachers satisfied the need for competence more than the peers, according to the students $\left(t_{\text {paired }}(584)=3.4, p=.001\right)$.

\section{Maladaptive behavior in relation to psychological needs}

Multilevel regression analyses were used to assess the extent to which the four types of maladaptive behavior correlated with the perceived fulfillment of students' need for competence, autonomy, and relatedness by teachers and peers. Table 3 shows the results of the final models.

\section{Supporting role of teachers}

The supporting role of teachers is found for three out of four outcome measures: maladaptive behavior toward schoolwork, unfriendly behavior, and withdrawn behavior. None of the teacher variables were significant for delinquent behavior, however. Further, different SDT variables were related to the distinguished types of maladaptive behavior. Our analyses showed a significant, negative correlation between maladaptive student behavior toward school and the extent to which students feel that teachers meet their need for autonomy and relatedness. The degree to which teachers are seen as meeting students' need for competence was negatively related to both unfriendly and withdrawn behavior.

\section{Supporting role of peers}

The assumed role of peers is found for three out of four outcome measures: maladaptive behavior toward schoolwork, withdrawn behavior, and delinquent behavior. No relation was found between peer variables and unfriendly behavior. The perceived support of the need for autonomy by peers showed, as expected, a negative correlation with maladaptive behavior toward schoolwork, withdrawn behavior, and delinquent behavior. Hence, this variable proved to be a robust predictor. Relatedness with peers was negatively related to students' withdrawn behavior, as expected. 
Table 3 Final multilevel models (per type of maladaptive behavior), beta weights, and standard errors of measurement

\begin{tabular}{|c|c|c|c|c|}
\hline Variables & $\begin{array}{l}\text { Maladaptive behavior toward } \\
\text { school(work) }\end{array}$ & $\begin{array}{l}\text { Unfriendly } \\
\text { behavior }\end{array}$ & $\begin{array}{l}\text { Withdrawn } \\
\text { behavior }\end{array}$ & $\begin{array}{l}\text { Delinquent } \\
\text { behavior }\end{array}$ \\
\hline Fixed factors: intercept & $1.350(.018)^{*}$ & $.227(.026)^{*}$ & $1.306(.018)^{*}$ & $\begin{aligned}- & 4.317 \\
& (.514)^{*}\end{aligned}$ \\
\hline \multicolumn{5}{|l|}{ Background variables } \\
\hline Gender $(1=$ male $)$ & $.036(.019)$ & $.148(.026)^{*}$ & $-.010(.018)$ & $.969(.405)^{*}$ \\
\hline Grade & $.093(.023)^{*}$ & $.147(.023)^{*}$ & $.122(.023)^{*}$ & $1.397(.476)^{*}$ \\
\hline $\begin{array}{l}\text { Educational level } \\
\qquad(1=\text { pre-vocational })\end{array}$ & $.010(.024)$ & $-.041(.035)$ & $-.012(.025)$ & $-.346(.450)$ \\
\hline $\begin{array}{l}\text { Education level father } \\
\quad(1=\text { low })\end{array}$ & $.020(.021)$ & $.085(.034)^{*}$ & $.048(.024)^{*}$ & $.006(.497)$ \\
\hline $\begin{array}{l}\text { Education level mother } \\
\quad(1=\text { low })\end{array}$ & $.000(.023)$ & $-.033(.035)$ & $-.052(.025)^{*}$ & $.604(.461)$ \\
\hline Identification as Dutch & $-.044(.023)$ & $-.112(.032)^{*}$ & $-.053(.023)^{*}$ & $-.899(.391)^{*}$ \\
\hline Social desirability & $.195(.028)^{*}$ & $.384(.045)^{*}$ & $.138(.032)^{*}$ & $1.452(.593)^{*}$ \\
\hline \multicolumn{5}{|l|}{ Interaction effect } \\
\hline $\begin{array}{l}\text { Grade } \times \text { pre-university } \\
\text { level }\end{array}$ & $.007(.027)$ & $-.041(.038)$ & $-.099(.026)^{*}$ & $\begin{aligned}-1.186 \\
(.587)^{*}\end{aligned}$ \\
\hline \multicolumn{5}{|l|}{ Teacher variables } \\
\hline Competence & $-.036(.020)$ & $-.074(.031)^{*}$ & $-.058(.022)^{*}$ & $-.742(.464)$ \\
\hline Autonomy & $-.057(.020)^{*}$ & $-.016(.032)$ & $-.000(.023)$ & $-.177(.462)$ \\
\hline Relatedness & $-.061(.019)^{*}$ & $-.053(.029)$ & $.037(.021)$ & $-.578(.417)$ \\
\hline \multicolumn{5}{|l|}{ Peer variables } \\
\hline Competence & $-.016(.012)$ & $-.007(.018)$ & $-.004(.013)$ & $.002(.283)$ \\
\hline Autonomy & $-.026(.013)^{*}$ & $.018(.021)$ & $-.061(.015)^{*}$ & $-.534(.256)^{*}$ \\
\hline Relatedness & $.016(.014)$ & $-.029(.021)$ & $-.105(.015)^{*}$ & $-.352(.277)$ \\
\hline \multicolumn{5}{|c|}{ Variance components (initial and end model) } \\
\hline \multirow[t]{2}{*}{ School level } & $.024(.005)^{*}$ & $.042(.011)^{*}$ & $.009(.005)$ & $.736(.625)$ \\
\hline & $.010(.003)^{*}$ & $.001(.006)$ & $.000(.000)$ & $.246(.570)$ \\
\hline \multirow[t]{2}{*}{ Class level } & $.013(.004)^{*}$ & $.013(.014)$ & $.021(.007)^{*}$ & $.000(.000)$ \\
\hline & $.011(.004)^{*}$ & $.023(.010)^{*}$ & $.008(.004)^{*}$ & $.000(.000)$ \\
\hline \multirow[t]{2}{*}{ Student level } & $.017(.003)^{*}$ & $.072(.011)^{*}$ & $.029(.004)^{*}$ & - \\
\hline & $.016(.002)^{*}$ & $.055(.008)^{*}$ & $.031(.004)^{*}$ & - \\
\hline \multicolumn{5}{|l|}{ Explained variance $(\%)$} \\
\hline Overall & 31.5 & 37.8 & 33.9 & 73.2 \\
\hline Background variables & 24.1 & 30.0 & 18.6 & 66.6 \\
\hline Basic needs & 7.4 & 7.8 & 15.3 & 6.6 \\
\hline
\end{tabular}

*Significant predictors $(p<.05)$ have been marked by an asterisk. Delinquent behavior is a binominal variable, which has been analyzed using a logarithmic regression model. The explained variance for basic needs is the incremental, the explained variance after the background variables have been taken into account in the analysis model

\section{Comparison of teacher and peer support}

The results for teachers (hypothesis 1) and peers (hypothesis 2) show different patterns for the competency, autonomy, and relatedness variables (see Table 3). For maladaptive behavior toward schoolwork, autonomy seems important at both teacher and peer levels and, hence, the results show convergent results for this variable. For unfriendly behavior, a different pattern emerged with a supporting role at the teacher level but not at the peer level. Interestingly, the results for withdrawn behavior suggest complementary roles for teacher and peer support: only meeting the need for competence at the teacher level is related to withdrawn behavior, whereas 
autonomy and relatedness are relevant factors at the peer level. Finally, delinquent behavior was only related to autonomy at the peer level.

The "explained" variance percentages for the SDT variables only differed per model, varying from a low 7\% for delinquent behavior (i.e., $9 \%$ of the total explained variance of the regression model) to a high $15 \%$ for withdrawn behavior (i.e., $45 \%$ of the total explained variance of the regression model).

\section{Relations with other variables}

The background variables from our model showed some statistically significant relationships with the four types of maladaptive behavior as well. There was a significant gender effect with regard to unfriendly and delinquent behavior: male students reported considerably more unfriendly behavior and delinquent behavior than female students (see Table 3). There were no differences between male and female students related to self-reported maladaptive behavior toward school(work) and withdrawn behavior. In addition to gender differences, we also observed an increasing trend for grade: older students reported significantly more maladaptive behavior on all SMBS subscales. The difference between grades 8 and 9 for maladaptive behavior toward school and schoolwork, unfriendly, and withdrawn behavior is approximately one third of a pooled standard deviation.

A further finding is that students' withdrawn behavior is negatively correlated with the education level of mothers and a positive correlation with the education level of fathers. Maladaptive student behavior at school showed a negative correlation with students' cultural background: the less students identify themselves as Dutch, the more unfriendly, withdrawn, and delinquent behavior they reported. Social desirability bias was related to all four types of behavior problems. Finally, the interaction effect between grade and students from the highest educational level (UNI) was statistically significant for two outcome measures; they reported less maladaptive behavior than other students. Therefore, this interaction effect was added to the background variables in our statistical model.

\section{Discussion}

The results show significant, negative correlations between the various types of maladaptive behavior at school and the extent to which students feel their teachers and peers meet their basic psychological needs: students who are supported by their teachers and peers report less maladaptive behavior. In general, this finding supports both hypothesis 1 and 2 that the extent to which teachers and peers meet the basic psychological needs of individual students is related to maladaptive behavior in the classroom, also when other demographic variables have been taken into account. When we differentiate between the different types of maladaptive behavior, as measured with the SMBS, deviant patterns occur.

Regarding maladaptive behavior toward school and schoolwork, there is a negative correlation between this behavior and the extent to which students perceive that teachers meet their need for autonomy and relatedness. As far as peers are concerned, the extent to which they meet the need for autonomy is particularly important. In case of maladaptive behavior regarding school and schoolwork (e.g., distracting other students or cutting class), it is not surprising that a perceived lack of need for autonomy from both teachers and peers is significant predictors. For example, if students experience that teachers or peers, without 
further explanation, do not allow them to carry out own initiatives, this may provoke students' oppositional behavior. This might even be enhanced if a teacher does not meet the need for relatedness either.

For unfriendly behavior of students, we found only competence support by the teacher to be a key factor, whereas autonomy and relatedness appeared to be non-significant factors. Peers seem to have no role in this type of behavior. This may be attributed to the fact that unfriendly behavior is disruptive, externalized maladaptive behavior that often targets teachers (e.g., provoking or ridiculing teachers). A possible explanation is that unfriendly behavior might be triggered by students' frustration with teachers who - despite the fact that the students feel a relationship with their caring teachers - offer too little structure to help students feel competent. A concrete example of lack of competence support is when teachers are not able to make clear what they expect from their students in performing a particular task, or when they do not provide clear explanations and feedback.

Students' perceived support of the teachers fostering their sense of competence is a key factor for students' withdrawn behavior in the classroom. Also, peers play an important role in the context of withdrawn behavior, and the extent to which they meet students' need for autonomy has a significant, positive relation as well. Further, students' perception of appreciation from their peers appears to be clearly correlated with withdrawn behavior (e.g., lack of class participation or isolating themselves from fellow students): withdrawn behavior is also negatively related, as may be expected, with students' sense of relatedness with peers.

We found no significant correlation between the extent to which teachers meet the three basic needs and the frequency with which students display delinquent behavior. Hence, delinquent behavior (e.g., destroying school property or taking other people's belongings without asking), which is rarely reported, may be impervious to positive treatment from their teachers. Moreover, delinquent behavior does not seem to correlate with the extent to which students feel their peers reinforce their sense of relatedness and competence. There is, however, a significant, negative correlation between delinquent behavior and students' perception of whether their peers meet their need for autonomy: if peers do not meet the need for autonomy, students are more declined to show delinquent behavior. Perhaps the extent to which peers meet each other's need for autonomy is an indication of mutual understanding and an independent position within the group. Students whose autonomy is not respected by peers may feel less important and/or respected as a person within the peer group, which they want to compensate with unwanted and tough behavior in order to conquer a position.

The findings from our study also show a reasonably positive picture of students' evaluations of teachers and peers meeting their psychological needs. Students' perceptions of teachers and fellow students meeting their need for competence, autonomy, and relatedness generally range from neutral to satisfied. Teachers and students seem to have different and partially complementary roles. Particularly with regard to the need for autonomy and relatedness, students feel that their peers are better at meeting their needs than teachers. Some gender differences surfaced. For example, more male than female students reported that their teachers did not do so well in meeting their basic needs. In terms of peer support, we found a difference between male and female students only for competence. Male students reported lower scores regarding their need for competence than female students. Finally, we also found differences between educational levels and grades. For all three basic needs on the SDT scales in both the TASQ for teacher and that for peers, the highest scores were found at the pre-university level, followed by general and pre-vocational secondary education, respectively. For all educational 
levels, students in grade 9 were less satisfied with the extent to which their teachers met their need for competence and autonomy than students in grade 8 .

Overall, clear patterns emerged regarding maladaptive behavior and gender, grade, and educational level. Male students reported unfriendly and delinquent behavior and maladaptive behavior toward school and schoolwork significantly more frequently than female students. Students in grade 9 of all educational levels reported significantly more maladaptive behavior than those in grade 8 . These outcomes are in line with earlier studies, which indicated that male students tend to display more maladaptive behavior than female students and older students more than younger students (Koerhuis and Oostdam 2014; Moffitt 1993; Murteira Morgado and Da Luz Vale-Dias 2013). In terms of educational level, we found a consistent pattern: students in pre-vocational education reported more maladaptive behavior than students in general secondary education, who, in turn, reported more maladaptive behavior than preuniversity students. However, these differences were small and statistically non-significant.

\section{Limitations of our study}

Obviously, our study has some limitations. Firstly, it is a correlational study and therefore does not imply any causality. Maladaptive behavior may have different causes, in addition to the psychological needs this study focuses upon. Furthermore, students' maladaptive behavior can be both a cause and a consequence of teachers' behavior and, therefore, should be analyzed from a transactional point of view. Teachers can elicit certain student behavior, but students, in turn, can also elicit particular teacher behavior. Therefore, maladaptive behavior should always be analyzed in a context that includes teachers' point of view.

Second, the present study has not taken teachers' perceptions into account. It is, therefore, important to note that students' perceptions of whether teachers meet their basic needs do not necessarily correspond to teachers' actual attempts. To gain a better understanding of the latter, researchers would need to observe lessons in the classroom or have teachers fill out questionnaires.

Third, individual differences between teachers are not taken into account. Students were asked about their teachers in general rather than about individual teachers. In future research, more attention must be paid to individual teacher characteristics in relation to maladaptive behavior of their students in the classroom. From a practical perspective, it does not seem feasible to collect data for all students' secondary school teachers (students in secondary school may have, for example, 14 teachers). Besides, it is doubtful whether students can give valid answers in such an elaborative procedure. In future studies, it would be interesting to further investigate the measurement procedure. It is possible to collect data for teachers in general (as in this study), but it is also possible to let students fill out a questionnaire with a single, designated teacher in mind. Although this procedure may seem more concrete for students, a distinct disadvantage is that it certainly limits the scope of a study in the context of secondary schools where students have a relatively large number of teachers.

Finally, students reported little maladaptive behavior in general. It is unclear to what extent this results from social desirability bias, but our analyses show that such bias is related to all four self-reported types of maladaptive behavior. This makes it plausible that students underreported the maladaptive behavior they actually display in the school environment. Furthermore, it was difficult to clearly analyze students' delinquent behavior because the behavior was reported so infrequently. Even so, it is important to learn more about the factors that influence delinquent behavior, as it is particularly this type of behavior that has a serious impact on teachers, peers, and the learning environment at school. 


\section{Implications for practice}

Based on the results of the present study, some preliminary implications for practice can be discussed. In summary, the significant correlations between students' maladaptive behavior and the extent to which their basic psychological needs are met support the hypothesis that meeting students' need for competence, autonomy, and relatedness correlates with less maladaptive behavior at school. These findings are consistent with other research that has shown the impact of a good teacher-student relationship on student motivation (cf. Roorda et al. 2011) and behavioral problems (Dutch Education Council 2010).

The results of the present study indicate, in accordance with a previous study (Koerhuis and Oostdam 2014), that the older the students get, the more important it becomes for teachers to take their psychological need concerning competence and autonomy into account. Although further research is needed to determine whether the observed changes in the psychological needs can be generalized to other student populations and whether the influence of these needs become more important in higher grades, it can be recommended to respond adequately to these needs in education in order to reduce maladaptive behavior in the classroom. For example, teachers and/or student supervisors could involve students more in developing cognitive tasks, generating activities, and drawing up rules of conduct. Other key factors include developing a close personal bond with students and responding to students' personal interests and motivation. In addition, attention for the underlying causes of maladaptive behavior and the group dynamics in the classroom is important in the school context. For example, when teachers notice a student shows increasingly withdrawn behavior in school, they may try to help the student by improving the relationship and cooperation with peers. A possible way of doing this is asking what the student experiences when working together with classmates and asking what kind of agreements he or she finds helpful when working with peers for school. Teachers could, for example, monitor how these joint school projects are actually carried out and check whether they are helpful for the student or merely lead to frustration (e.g., peers telling the student what to do).

Our findings strongly suggest that students' maladaptive behavior in school can be influenced by both the teacher and the peers. The picture that emerges from our study is that students need satisfaction of all psychological needs by the teacher to prevent or reduce different types of maladaptive behavior, whereas they need satisfaction of autonomy and relatedness from their peers. In the context of school, it seems that maladaptive behavior of students may be influenced not only by the hierarchical teacher-student relationship but also by the social peer system in the class.

Open Access This article is distributed under the terms of the Creative Commons Attribution 4.0 International License (http://creativecommons.org/licenses/by/4.0/), which permits unrestricted use, distribution, and reproduction in any medium, provided you give appropriate credit to the original author(s) and the source, provide a link to the Creative Commons license, and indicate if changes were made.

\section{References}

Achenbach, T. M. (1991). Manual for the youth self reports and 1991 profile. Burlington: Department of Psychiatry, University of Vermont.

Achenbach, T. M., \& Edelbrock, C. (1986). Manual for the teacher's report form and teacher version of the child behaviour profile. Burlington: Department of Psychiatry, University of Vermont. 
Belmont, M., Skinner, E., Wellborn, J., \& Connel, J. (1992). Teacher as social context (TASC). Two measures of teacher provision of involvement, structure, and autonomy support. Rochester: University of Rochester.

Berndt, T., \& Keefe, K. (1996). Friends' influence on school adjustment: A motivational analysis. In J. Juvonen \& K. Wentzel (Eds.), Social motivation: Understanding school adjustment. New York: Cambridge University Press.

Deci, E., \& Ryan, R. (2000). The 'what' and 'why' of goal pursuits: human needs and the self-determination of behavior. Psychological Inquiry, 11(4), 227-268.

Deci, E. L., Ryan, R. M., \& Koestner, R. (1999). A meta-analytic review of experiments examining the effects of extrinsic rewards on intrinsic motivation. Psychological Bulletin, 125(6), 627-668.

Dornbusch, S. M., Glasgow, E., Laird, J., \& Wong, C. A. (2001). The relation of family and school attachment to adolescent deviance in diverse groups and communities. Journal of Adolescent Research, 16(4), 396-422.

Driessen, G. (2007). 'Peer group' effecten op onderwijsprestaties; Een internationaal review van effecten, verklaringen en theoretische en methodologische aspecten. [Peer group effects on educational performance; An international review of effects, explanations, and theoretical and methodological aspects.] Nijmegen: ITS, Radboud Universiteit.

Eccles, J. S., \& Roeser, R. W. (2009). Schools, academic motivation and stage-environment fit. In R. Lerner \& L. Steinberg (Eds.), Handbook of adolescent psychology (2nd ed., pp. 404-434). New York: Wiley.

Fergusson, D. M., Horwood, L. J., \& Ridder, E. M. (2005). Show me the child at seven: the consequences of conduct problems in childhood for psychosocial functioning in adulthood. Journal of Child Psychology and Psychiatry, 46(8), 837-849.

Hattie, J., \& Timperley, H. (2007). The power of feedback. Review of Educational Research, 77(1), 81-112.

Helwig, C. (2006). The development of personal autonomy throughout cultures. Cognitive Development, 21(4), $458-473$.

Jang, H., Reeve, J., \& Deci, E. L. (2010). Engaging students in learning activities: it is not autonomy support or structure, but autonomy support and structure. Journal of Educational Psychology, 102(3), 588-600.

Koerhuis, M. J. C. (2007). Maladaptive social behaviour of students in secondary vocational education. Leiden: Universiteit Leiden.

Koerhuis, M. J. C., \& Hijzen, D. M. (2009). Handleiding Vragenlijst Sociaal Ongewenst Gedrag Op School (SOGOS). [Manual questionnaire maladaptive behavior at school.]. Den Haag: HenK Onderwijsadvies- en Onderzoeksbureau.

Koerhuis, M., \& Oostdam, R. (2014). Ongewenst gedrag van vmbo-leerlingen en hun behoefte aan autonomie, competentie en sociale relaties. [Maladaptive behavior of students in the lower vocational track of Dutch secondary education in relation to their psychological needs.]. Tijdschrift voor Orthopedagogiek, 53, 117-131.

LeBlanc, L., Swisher, R., Vitaro, F., \& Tremblay, R. (2008). High school climate and antisocial behavior: a 10year longitudinal and multilevel study. Journal of Research on Adolescence, 18(3), 395-419.

Maguin, E., \& Loeber, R. (1995). Academic performance and delinquency. In M. Tonry (Ed.), Crime and justice: An annual review of research (Vol. 20, pp. 145-264). Chicago: University of Chicago Press.

Meijers, F., Kuijpers, M., \& Bakker, J. (2006). Over leerloopbanen en loopbaanleren. [About careers and career learning.]. Driebergen: HPBO.

Moffitt, T. E. (1993). Adolescence-limited and lifecourse-persistent anti-social behavior: a developmental taxonomy. Psychological Review, 100(4), 674-701.

Moffitt, T.E. and Caspi, A. (2001). Childhood predictors differentiate life-course persistent and adolescencelimited antisocial pathways among males and females. Development and Psychopathology, 13, 355-375.

Moffitt, T. E., Caspi, A., Harrington, H., \& Milne, B. J. (2002). Males on the life-course-persistent and adolescence-limited antisocial pathways: follow-up at age 26 years. Development and Psychopathology, 14(1), 179-207.

Murteira Morgado, A., \& Da Luz Vale-Dias, M. (2013). The antisocial phenomenon in adolescence: what is literature telling us? Aggression and Violent Behavior, 18(4), 436-443.

Nederhof, A. (1981). Beter onderzoek: Bestrijding van foutenbronnen in sociaal-wetenschappelijk onderzoek. [Better research: combating error sources in social science research]. 's-Gravenhage: VUGA Uitgeverij.

Niemiec, C., \& Ryan, R. (2009). Autonomy, competence and relatedness in the classroom. Applying selfdetermination theory to educational practice. Theory and Research in Education, 7(2), 133-143.

O’Moore, M., \& Kirkham, C. (2001). Self-esteem and its relationship to bullying behavior. Aggressive Behavior, 27(4), 269-283.

Olweus, D., Block, J., \& Radke-Yarrow, M. (1986). Introduction. In D. Olweus, J. Block, \& M. Radke-Yarrow (Eds.), Development of antisocial and prosocial behaviour: Research, theories and issues (pp. 16-50). Orlando: Academic. 
Onderwijsraad [Dutch Education Council]. (2010). De school en leerlingen met gedragsproblemen. [The school and pupils with behavioral problems.]. Den Haag: Onderwijsraad.

Oostdam, R., Peetsma, T., \& Blok, H. (2007). Het nieuwe leren in basisonderwijs en voortgezet onderwijs nader beschouwd: Een verkenningsnotitie voor het Ministerie van Onderwijs, Cultuur en Wetenschappen. [New learning in primary and secondary education: A review study for the Dutch Ministry of Education.] Amsterdam: SCO-Kohnstamm Instituut.

Peetsma, T., \& Van der Veen, I. (2011). Relations between the development of future time perspective in three life domains, investment in learning, and academic achievement. Learning and Instruction, 21(3), 481-494.

Pintrich, P., \& Schunk, D. (2002). Motivation in education: Theory, research and applications (2nd ed.). Upper Saddle River: Merrill Prentice Hall.

Rasbash, J., Steele, F., Browne, W. J., \& Goldstein, H. (2009). A user's guide to MLwiN 2.10. Bristol: Centre for Multilevel Modelling, University of Bristol.

Reeve, J., Deci, E. L., \& Ryan, R. M. (2004). Self-determination theory: A dialectical framework for understanding socio-cultural influences on student motivation. In D. M. McInerney \& S. van Etten (Eds.), Big theories revisited (pp. 31-60). Greenwich: Information Age.

Roeser, R. W., Van der Wolf, K., \& Strobel, K. R. (2001). On the relation between social-emotional and school functioning during early adolescence: preliminary findings from Dutch and American samples. Journal of School Psychology, 39(2), 111-139.

Roorda, D., Koomen, H., Spilt, J., \& Oort, F. (2011). The influence of affective teacher-student relationships on students' school-engagement and achievement: a meta-analytic approach. Review of Educational Research, 81(4), 493-529.

Schuit, H., De Vrieze, I., \& Sleegers, P. (2011). Leerlingen motiveren: Een onderzoek naar de rol van leerkrachten. [Motivate students: An investigation into the role of teachers.]. Heerlen: Ruud de Moor Centrum, Open Universiteit.

Schuitema, J., Peetsma, T., \& van der Veen, I. (2016). Longitudinal relations between perceived autonomy and social support from teachers and students' self-regulated learning and achievement. Learning and Individual Differences, 49, 32-45.

Séguin, J. R., Parent, S., Tremblay, R. E., \& Zelazo, P. D. (2009). Different neurocognitive functions regulate physical aggression and hyperactivity in early childhood. Journal of Child Psychology and Psychiatry, 50(6), 679-687.

Sheldon, K., \& Bettencourt, B. (2002). Psychological need-satisfaction and subjective well-being within social groups. British Journal of Social Psychology, 41(1), 25-38.

Sierens, E., Vansteenkiste, M., Goossens, L., Soenens, B., \& Dochy, F. (2009). The synergistic relationship of perceived autonomy support and structure in the prediction of self-regulated learning. British Journal of Educational Psychology, 79(1), 57-68.

Standage, M., Duda, J. L., \& Ntoumanis, N. (2006). Students' motivational processes and their relationship to teacher ratings in school physical education: a self-determination approach. Research Quarterly for Exercise and Sport, 77(1), 100-110.

Van der Laan, A.M., \& Blom, M. (2006). WODC Monitor Zelfgerapporteerde Jeugdcriminaliteit, Meting 2005: Documentatieboek steekproefverantwoording, veldwerk, enquête en vergelijking met eerdere metingen. [Monitor self-reported youth criminality, measurement 2005: Documentation book sample accountability, fieldwork, survey and comparison with previous measurements.] Den Haag: WODC.

Van der Ploeg, J. D. (2007). Behandeling van gedragsproblemen. Initiatieven en inzichten. [Treatment of behavior problems: initiatives and insights.]. Rotterdam: Lemniscaat.

Van der Wolf, K., \& van Beukering, T. (2009). Gedragsproblemen in scholen. Het denken en handelen van leraren. [Behavioral problems in schools. The thoughts and actions of teachers.]. Leuven: Acco.

Vansteenkiste, M., Ryan, R. M., \& Deci, E. L. (2008). Self-determination theory and the explanatory role of psychological needs in human wellbeing. In L. Bruni, F. Comim, \& M. Pugno (Eds.), Capabilities and happiness (pp. 187-223). Oxford: Oxford University Press.

Vansteenkiste, M., Sierens, E., Goossens, L., Soenens, B., Dochy, F., Mouratidis, A., Aelterman, N., Haerens, L., \& Beyers, M. (2012). Identifying configurations of perceived teacher autonomy support and structure: associations with selfregulated learning, motivation and problem behavior. Learning and Instruction, 22(6), 431-439.

Vazsonyi, A., \& Pickering, L. E. (2000). Family processes and deviance a comparison of apprentices and nonapprentices. Journal of Adolescent Research, 15(3), 368-391.

Veenstra, R., Lindenberg, S., Tinga, F., \& Ormel, J. (2010). Truancy in late elementary and early secondary education: the influence of social bonds and self-control. The TRAILS study. International Journal or Behavioral Development, 34(4), 302-310.

Wentzel, K. (1996). Social goals and social relationships as motivators of school adjustment. In J. Juvonen \& K. R. Wentzel (Eds.), Social motivation: Understanding school adjustment (pp. 226-247). New York: Cambridge University Press. 
Ron Oostdam. Centre for Applied Research in Education (CARE), Amsterdam University of Applied Sciences, Wibautstraat 2-4, 1091 GM, Amsterdam, The Netherlands. E-mail: r.j.oostdam@ @va.nl.

Current themes of research:

Differentiation in learning and instruction. Motivation. Cognitive processes for language learning. (Early) literacy development. Child care and development. Parental involvement. Test anxiety and learning potential. Preschool, primary, and secondary education.

Most relevant publications in the field of Psychology of Education:

Van Batenburg, E., Oostdam, R. J., van Gelderen, A., \& De Jong, N. (2018). Measuring L2 speakers' interactional ability using interactive speech tasks. Language Testing, 35(1), 75-100.

Teepe, R. C., Molenaar, I., Oostdam, R., Fukkink, R., \& Verhoeven, L. (2017). Children's executive and social functioning and family context as predictors of preschool vocabulary. Learning and Individual Differences, $57,1-8$.

Van Steensel, R., Oostdam, R., Van Gelderen, A., \& Van Schooten, E. (2016). The role of word decoding, vocabulary knowledge and meta-cognitive knowledge in monolingual and bilingual low-achieving adolescents' reading comprehension. Journal of Research in Reading, 39(3), 312-329.

Oostdam, R., Blok, H., \& Boendermaker, C. (2015). Effects of individualised and small-group guided oral reading interventions on reading skills and reading attitude of poor readers in grades 2-4. Research Papers in Education, 30(4), 427-450.

Steensel, R., R. Oostdam, \& Van Gelderen, A. (2013). Assessing reading comprehension in adolescent low achievers: subskills identification and task specificity. Language Testing, 30(1), 3-21.

Oostdam, R., \& Hooge, E. (2013). Making the difference with active parenting; forming educational partnerships between parents and schools. European Journal of Psychology of Education, 28(2), 337-351.

Oostdam, R., \& Meijer, J. (2011). Effects of instruction and stage-fright on intelligence testing. European Journal of Psychology of Education, 26(1), 143-161.

Marie-José Koerhuis. Centre for Applied Research in Education (CARE), Amsterdam University of Applied Sciences, Wibautstraat 2-4, 1091 GM, Amsterdam, The Netherlands. E-mail: m.c.koerhuis@hva.nl.

Current themes of research:

Maladaptive social behavior of students in secondary vocational education. Motivation, maladaptive behavior, and well-being of pupils and students.

Most relevant publications in the field of Psychology of Education:

Koerhuis, M. J. C. (2007). Maladaptive social behaviour of students in secondary vocational education. Leiden: Leiden University.

Koerhuis, M. J. C. \& Hijzen, D. M. (2009). Handleiding Vragenlijst Sociaal Ongewenst Gedrag Op School (SOGOS). [Manual questionnaire maladaptive behavior at school.] Den Haag: HenK Onderwijsadvies- en Onderzoeksbureau.

Koerhuis, M., \& Oostdam, R. (2014). Ongewenst gedrag van vmbo-leerlingen en hun behoefte aan autonomie, competentie en sociale relaties. [Maladaptive behavior of students in the lower vocational track of Dutch secondary education in relation to their psychological needs.] Tijdschrift voor Orthopedagogiek, 53, 117-131. 
Ruben Fukkink. Centre for Applied Research in Education (CARE), Amsterdam University of Applied Sciences, Wibautstraat 2-4, 1091 GM, Amsterdam, The Netherlands. E-mail: r.g.Fukkink@ hva.nl.

Current themes of research:

Professional development of staff and effects on the development of young children. Video feedback. Language learning.

Most relevant publications in the field of Psychology of Education:

Egert, F., Fukkink, R. G., \& Eckhardt, A. (2018). Impact of in-service professional development programs for early childhood teachers on quality ratings and child outcomes. Review of Educational Research, doi.org/10.3102/0034654317751918.

Fukkink, R. G., Jilink, L., \& Oostdam, R. J. (2017). A meta-analysis of the impact of early childhood interventions on the development of children in the Netherlands: an inconvenient truth? European Early Childhood Education Research Journal, 25(5), 656-666.

Nieuwboer, C. C., Fukkink, R. G., \& Hermanns, J. M. A. (2015). Adherence to and effects of the use of the guiding the empowerment process model in single session email consultation. British Journal of Guidance \& Counselling, 43(1), 131-143.

Fukkink, R.G., Trienekens, N, \& Kramer, L.J.C. (2011). Video feedback in education and training: putting learning in the picture. Educational Psychology Review, 23(1), 45-63.

Fukkink, R.G., \& Tavecchio, L.W.C. (2010). Effects of video interaction guidance on early childhood teachers. Teaching and Teacher Education, 26(8), 1652-1659.

Fukkink, R.G., \& Lont, T.A.E. (2007). Does training matter? A meta-analysis and review of experimental studies of caregiver training. Early Childhood Research Quarterly, 22(3), 294-311.

Fukkink, R. (2005). Deriving word meaning from context: a process analysis. Learning \& Instruction, $15(1), 23-43$. 